\title{
PERJUANGAN DIPLOMASI INDONESIA
}

FAHMI IKHSAN ARIFUDDIN

90100121086

\section{FAKULTAS EKONOMI DAN BISNIS ISLAM \\ JURUSAN EKONOMI ISLAM}

\section{PENDAHULUAN}

Kemerdekaan indonesia diraih dilakukan kerja keras dari seluruh rakyat indonesia.proklamasi kemerdekaan dikuamdangkan pada tanggal 17 agustus 1945 yang artinya bangsa indonesia telah bebas dari penjajahan dari bangsa asing.perjuangan lah diplomasi indonesia banyak sekali kejadian peperangan antara negara.Dimulai dari setelah indnesia menyatakan merdeka atas kekalahan jepang pada tahun 1945 sampai pada tahun 1950.Belanda pun tidak senang jika indonesia telah menyatakan kemerdekaan maka melanda pun melakukan agresi militer sebagai bentuk penindasan dan ancaman bagi negara.ada empat tahap setelah kemerdekaan indonesia dimulai dari perjanjian linggarjati,agresi milter I,agresi militer II,tujuan sebenarnya Roem Royen dan konferensi meja bundar.

Pada masa sekarang ini sejarah itu mulai hilang dan enggan mengetahuinya maka nanti generasi selanjutnya tidak akan mengetahui sejarah seperti apakah yang pernah terjadi.sejarah harus dipelajari tiap hari agar kita tahu pengorbanan negara dalam memerdakan negara indonesia.Maka dari itulah penelitian ini dibuat agar dapat memahaimi bahwa sejarah kemerdekaan itu penting dan kita dapat belajar dari sejarah itu sendiri. 
A.Perjanjian linggarjati

Perjanjian linggarjati merupakan perjanjian yang muncul setelah belanda melakukan penyerangan terhadap indonesia pasca diumumkannya kemerdekaan indonesia pada tanggal 17 agustus 1945.Perjanjian linggarjati merupakan jalan bagi indonesia untuk mendapatkan pengakuan dari dunia internasional.

Adapun tokoh tokoh dalam perjanjian linggarjati sebagai berikut;

a). Delegasi belanda; hbertus van mook dan prof.Dr.Ir.W.Schemerthorn

b). Delegasi indonesia; soetan sjahrir,A.K Gani,Amir sjafruddin,soesanto titoprodjo

c). Delegasi inggris (pihak penengah); lord Inverchapel dan lord killearen.

Adapun hasil dari keptusannya dari perjanjian linggarjati

a). Belanda mengakui kekuasaan defacto indonesia( jawa,madura,dan sumatera)daerah yang dikuasai oleh belanda dan sekutu akan dikembalikkan

b). Berangsur-angsur dibentuk negara indonesia

c). Dibentuk negara republik indonesia serikat

d). Pemerintahan Belanda dan RI akan bentuk indonesia-belanda NIS dan UNI

e). Pemerintah RI mengakui akan memulihkan dan lindungi hak milik orang

f). Belanda sepakat mengurangi jumlah peelisihan dan diselesaikan oleh komite arbitrase

Dengan tercapainya persetujuan perjanjian linggarjati pada tanggal 15 november 1946 dan disahkan tanggal 25 maret 1947 dijakarta, namun situasinya membuat kepala kepala politik di indonesia semakin keruh.(hardyanto,F.Y.2010)

B. Agresi militer I

Tujuan belanda dalam agresi milter yang pertama ini belanda ingin merebut daerah daerah yng memiliki sumber daya alam,terutama minyak.

Point penting dalam agresi militer I kali ini ialah

A. Pda tanggal 21-7-1947 belanda menyerang indonesia dan menguasai seluruh pelabuhan di jawa.

b). Pada tanggal 29-8-1947 belanda deklarasikan garis genjatan senjatan van mook yang membuat wilayah indo semakin sempit

c). Pada tanggal 18-9-1947 komisi 3 negara di bentuk untuk menyelesaikan masalah yang terjadi. 


\section{Agresi militer II}

Sebagaimana belanda belum rela untuk melepaskan wilayah jajahannya di nusantara.Proklamasi kemerdekaan indonesia 17-8-1945,negara indonesia ingin diambil kemabli oleh belanda dengan berbagai cara salah satunya yaitu perundingan dan agresi militer dan dihentikan dengan perjanjian renville.

\section{Persetujuan Roen Royen}

Pada awalnya persetujuan roem royen tersebut tidqak di terima dikalangan politisi karena politisi beramsumsi bahwa ketika kita menerima hasil perundingan tersebut maka mereka beranggapan bahwa kita menerima kekalahan.Nqamun pada akhirnya pemerintah maupun rakyat indonesia menerima hasil dari persetujuan tersebut.

Ada pun hasil dari persetujuan tersebut ialah

a). Indonesia akan hentikan perang Gerilya,ikut dalam KMB Den Haag

b). Belanda mengembalikan rakya indonesia ke jogja,dan membebaskan seluruh politik dan menghentikan gerakan militernya.

E. Konferensi meja bundar

Pada tanggal 23 agustus sampai dengan 2 november 1949 telah mencaoai pesetujuan.

adapun hasil dari konferensi meja bundar sebagai berikut

a). Belanda mengakui rakyat indonesia serikat sebagai negara merdeka dan berdaulat

b). Masalah irian barat akan diselesaikan setahun kemudian

c). Pemerintakan rakyat indonesia serikat di atur dengan konstitusi oleh para delegasi $\mathrm{KMB}$ (konferensi meja bundar)

d). Akan dibentukna UNI indonesia-belanda yang sifatnya dilonggarkan

e). Rakyat indonesia serikat harus membayar hutang hindia belanda

f). Rakyat indonesia serikat akan dikembalikan hak milik belanda dan ksih izin unruk peusahan belanda.

Pada tanggal 16 desember 1949 soekarno terpilih menjadi presiden RI sementara Mr.assaat menjadi ketua KNIP dan kemudian RIS berakhir 17 agustus 1950 dan diganti menjadi NKRI. 


\section{Daftar Pustaka}

Sari, Dwi Eka,dkk. (2014). Tinjauan Historis Implementasi iss perjanjian Linggarjati dan belanda tahu 1946-1947.(jurnal pendidikan dan penelitian sejarah,2(4),1-13

Hardyanto,F.Y. (2010). perang mempertahankan kemerdekaan di kebumen tahun 19451950

Astuti, I. N. (2011). Perjuangan politik muhammad hatta pada masasistem pemerintah parlementer (1948-1956).

Sugiarto lesmana (20130 jurnal artefak. Perundingan roem roijen dalam perjuangan mempertahankan kemerdekaan republik indonesia tahun 1949

Budiman, Agus. "Sejarah Diplomasi Roem-Roijen Dalam Perjuangan Mempertahankan Kemerdekaan Republik Indonesia Tahun 1949." Jurnal wahana pendidikan 4, no. $1 ; 86-112$. 